\title{
Implementation of Spirituality-Crisis Counseling to Reduce Early Childhood Trauma
}

\author{
Dwi Bhakti Indri M. \\ Institut Pesantren KH. Abdul Chalim Mojokerto, Indonesia \\ @indrifaith@gmail.com
}

\section{Article Information: \\ Received January 11, 2018 \\ Revised January 18, 2018 \\ Accepted January 28, 2018}

Keywords:

Spirituality, Crisis Counseling,

Traumatic, Early Childhood.

\begin{abstract}
Events that left deep wounds has the potential to make people experiencing trauma. This matter cannot be separated in early childhood. Trauma in early childhood affects many different aspects of the development, both cognitive development, motor and socio-emotional. Spirituality-crisis counseling is a counseling service in the form of play therapy which integrated with the element of spirituality in its intervention. The goal is to reduce traumatic early childhood. There are five phase of spirituality-crisis counseling, among others initial phase, transitional phase, activity phase, termination phase, evaluation and follop up phase. This article attempts to explain the urgency of spirituality-crisis counseling in reducing traumatic early childhood.
\end{abstract}

\section{INTRODUCTION}

Earthquake and tsunami were occurred in Aceh 2004, around 7:58 pm, a magnitude 9.1 on the Richter scale (SR) hit Aceh, west coast peninsula of Malaysia, Thailand, the east coast of India, Sri Lanka, furthermore the east coast of Africa, then a few minutes later, tsunami wave crashing with devastating (Gunawan, 2014). These events resulted in hundreds of thousands victims in Indonesia and citizens of other countries.

In addition, there are other data whereas Indonesian citizens, we are still remember the earthquake in Yogyakarta in 2006, when the clock shows the number 5:53 pm, the earth shook terrific. The earthquake occurred just 57 seconds, but the impact was huge. Humans were lying on the roadside. People hurt and killed, the most victims are in Bantul, several studies have shown that children prone to trauma victims (Rohmadheny \& Yudiari, 2015).

Associated with traumatic, there is a variety antecedent of the condition trauma. In addition to natural disasters, violence. According to the WHO violence is the use of physical force and power, threats or acts of self, individual or group of people or community that resulted or might cause bruising or injury, death, psychological harm, abnormal development or deprivation. In addition, Seto Mulyadi (Chairman of the National Commission for the Protection of Children) stated that monitoring and conversations with many parents, she guessed 50-60 percent of parents do violence on children (Kompas, June 29, 2003). Ministry of Social Affairs also noted that as many as 43,708 children suffered physical violence spread across 27 provinces (Perempuan, 2013).

Associated with the breakdown of some of the above data, natural disasters, violent psychological and physical violence has the potential to leave deep wounds, including traumatic childhood. This traumatic is not only experienced by adults but also experienced by younger children. According to (Nawangsih, 2016) the victims are in a state of very quiet, very scared, never-ending anxiety, and become prone to panic. This matter will have a negative impact on children's development is complex if not given proper and prompt

How to cite :

E-ISSN:

Published by:

Available Online:
Indri M., D. B. (2018). Implementation of Spirituality-Crisis Counseling to Reduce Early Childhood Trauma. Islamic Guidance and Counseling Journal, 1(1), 25-32. https://doi.org/10.25217/igcj.v1i1.194 2614-1566

Institut Agama Islam Ma'arif NU (IAIMNU) Metro Lampung

https://journal.iaimnumetrolampung.ac.id/index.php/igcj 
intervention. Children with anxiety should receive assistance to overcome their issue (Maba, 2017). Counseling services can be provided as an intervention for children who have experienced traumatic. Counseling is a process of communication between counselor and counselee in an atmosphere of professional relationships by applying the techniques of counseling so that the counselor can help the counselee to address the problems being faced by the means at counselees have (Strauser, Lustig, Cogdal, \& Uruk, 2006).

Different types of counseling service forms, one of which is a crisis-counseling. Crisis counseling is appropriate given to children who experience traumatic event. This matter, due to the problems they are experiencing traumatic need as soon as possible to overcome. That problem is identical to the constraints on the development of children in a comprehensive manner. In this article, we will clarify one form of services crisis-counseling that are integrated with spirituality as an attempt to overcome or reduce traumatic for children.

\section{METHOD}

Author utilize content analysis method, this method attempt to organize and well ordered descriptively all concept related to the study to analyze the data. Content analysis method conducts a deep description of content, written information or printed in mass media (Arikunto, 2006). Data were collected with documentation method by gathered some article related to the study (Sugiyono, 2011). The contents were analyzed in this study are related to trauma, counseling, spirituality, childhood, and playtherapy. After the data above have been described and analyzed, the author attempt to presenting an innovative method in order to reduce early childhood trauma with Spirituality-Crisis Counseling.

\section{RESULT AND DISCUSSION}

\section{Trauma}

Trauma is the events which involve individuals in the show with an incident that allowed him injured or die so that it appears the feeling of terror and despair (Strauser et al., 2006). Trauma is an injury whether physical, physical and psychological. Trauma can cause anxiety disorder (Chaplin, 2001). Meanwhile, according to (Goleman, 2000) that the trauma patients experience changes limbic circuitry centered on the amygdala. So that trauma is an event that involves the individual result of an incident that may affect the physical, physical and psychological.

There are three kinds of major symptoms of trauma are: re-experiencing or recalling (Corrigan, Selassie, \& Orman, 2010). Trauma victims generally continue to experience or relive their trauma in the form that has bad memories such as images, perceptions, and thoughts related to the trauma, nightmares about an event, felt that the event will recur, physical symptoms such as sweating, heart beat faster, difficulty breathing when reminded of the traumatic event.

\section{Counseling}

Crisis-Crisis is a state of disorganization purpose of life or the life cycle of early childhood disorders and deep states. According (Geldard \& Geldard, 2011) crisis claimed the dangers which one of the causes of natural disasters such as earthquakes, hurricanes, floods, volcanic eruptions, tsunamis hurricanes. Four stages of counseling skills crisis is as follows: (1) assess or determine the current condition and the severity counselees problem; (2) The counselor then must decide what kind of counseling is most needed at this time based on the assessment of skills counselees adjustment; (3) act directly in the implementation of counseling; and (4) monitoring counselees real action to implement the results of counseling with real action in everyday life (Brammer \& Abrego, 1981; Carkhuff, 2008). Crisis counseling is unique and contributes, among others: this approach provides the advantage of being short and direct, this approach uses the object and purpose as simple as the nature of 
sudden and/or traumatic, this approach took place at a greater intensity than other forms of counseling usual, is more traditional (Rahayu, 2016). One form of crisis counseling services the right to apply for early childhood Trauma minimize disaster victims is play therapy.

\section{Spirituality}

Spirituality is often equated with religion (Mulyadi, 2016, 2017). However, there are differences between spirituality with religiosity. Spirituality is a human experience find meaning, purpose, and values, which may or may not, include the concept of God or transcendent beings (Plumb, 2011). The subject is reinforced by the notion that spirituality is a process of personal experience that aims to find something sacred in life and is an attempt to communicate with the Lord (Thoresen \& Harris, 2002).

\section{Childhood}

In early childhood, the child wants to play, exercise groups, browsing, asking, imitating and creating something. At this time, the child has made remarkable progress in the skills to help themselves and the skills to playing (Mulyadi, Christiana, Muhari, \& Wiryo Nuryono, 2013). With such characteristics, learning interesting and fun for children is always "wrapped" with games, singing and dancing a jovial mood. Not learning the approach that is filled with tasks that are heavy, especially with the level of knowledge, skills and habituation are not simple anymore as compelling to read, write and count with all the homework that unable to done by children (Riyanto \& Handoko, 2005).

By playing, children have the opportunity to explore, discover, express, create, and learn fun (Johnson, 2013). Experts agree that children must play in order to achieve optimal development. Without playing, children will be problematic in the future. Because of the play, children acquire the ability to control body, objects and social skills (Asmani, 2010). In fact, according to Moleong, playing is the most appropriate means for children to explore their world. The method of play(play therapy)becomes a tool for counselors to deal with the problems of children through counseling services, including in this case is a matter traumatic early childhood (Saputra \& Setianingrum, 2016). Playing is also able to develop selfconfidence and social skills (Erikson, 1963).

\section{Spirituality-Crisis Counseling to Reduce Traumatic Childhood Experience}

Development owned early childhood is very rapid. The development covers various aspects, including cognitive, psychomotor, socio-emotional and so forth. However, this valuable opportunity may be hampered by the existence of psychological distress, such as traumatic. One of the efforts in reducing traumatic experienced by younger children is to implement crisis-counseling. There are various forms of crisis counseling. If adjusted to the stage of early childhood development, form, crisis counseling proper ie play therapy. (Saputra \& Setianingrum, 2016) states that the method of play (play therapy) can be a tool for counselors to deal with the problems of children through counseling services, including in this case is the issue of early childhood traumatic disaster victims. Method of playing can be a media guidance and counseling services that appeal to young children because of the characteristics of early childhood that are still in play.

According to Landerth (Rohmadheny \& Yudiari, 2015) play therapy counseling is recommended as a medium for playing a child's natural expression. The deeper analysis of children who experience traumatic, there is a view of strengthening. The necessary design specific interventions for children who experience PTSD ie play therapy techniques (Nawangsih, 2016).

Play therapy is one of the techniques of cognitive behavior therapy.Regarding this, there is various research reveals that cognitive behavior therapy is integrated with spirituality is more effective than cognitive behavior therapy conventional (Berk et al., 2015; Koenig et al., 2015; Pearce et al., 2015). The first psychiatrist who introduced the spirituality in his writings, namely Scott Peck (Lines, 2006). According to Richards and Bergin (Lines, 2006), 
prescription spiritual counseling strategies, that God exists, man is created by God and is influenced by spiritual forces.

The Phase of Spirituality-Crisis Counseling (Wibowo, 2005; Homeyer \& Morrison, 2008; Gibson \& Mitchell, 2011; Gladding, 2012; Corey, 2012), among others:

\section{Initial Phase}

At this phase, there are several things that need to be emphasized, namely (a) fostering good relations, (b) self-inclusion, (c) agenda, (d) group norms, and (e) extracting ideas and feelings. Fostering good relationships, that efforts to reach rapport relationship between group members in order to know each other, empathy, and mutual respect. Self-involvement means the counselor's effort in creating rapport with members. Agenda, short and long term determination. Group norms, attempts to explain the purpose and procedure of group counseling. While extracting ideas and feelings, efforts in the achievement of commitment together and explore ideas and feelings that may still block.

\section{Transitional Phase}

It is an effort to foster interpersonal relationships (members) so that group members are ready to run the activities at a later stage. This stage can be continued to the phase of activities are very dependent on the readiness of group members. Not possible, the transition phase is repeated after the phase of activities if the group members have not been able to trust each other completely.

\section{Activity Phase}

At this phase, group members are directed to implement play therapy that has been planned by the counselor. Implementation of this play therapy is integrated with spirituality through a manualized approach. The process of integrating spirituality into play therapy is on the aspect of reflection or the termination stage. Play therapy is an effective means of responding to the mental health needs of young children and is accordingly accepted as a valuable and developmentally appropriate intervention. Meanwhile, spirituality is an effective approach to be great moslem child or people.

\section{Termination Phase}

At the termination phase, there are several things that can be done by counselors and group members. For example, reflecting on experience, evaluating what has been learned and so on. There are several elements of spirituality that can be described briefly, as follows: Surely with difficulty is ease. With difficulty is surely ease. (QS. Ash Sharh: 5-6)

\section{Evaluation and Follow Up Phase}

At the evaluation and follow-up phase, it consists of three parts. Namely, process evaluation, evaluation of results and follow-up. Associated with the evaluation of results, there are some things to focus on, such as new understanding, effects of activities, weakness, strength and so on. Related to the evaluation of the process, for example between the suitability of the program and implementation, obstacles, support and so on. While the followup is the implementation of the results of planning after the evaluation, both evaluation process and evaluation results.

\section{CONCLUSION}

There is the most visible negative impact on early childhood trauma is the inhibition of development in various aspects. One of the efforts to do to reduce childhood trauma is using play therapy integrated with spirituality. With the crisis counseling services form of play therapy and integrated with the value of spirituality, the author expected this treatment could reducing trauma in early childhood. There are five phases of spirituality-crisis counseling, among others initial phase, transitional phase, activity phase, termination phase, evaluation and follop up phase. Each phase has it's own characteristic and should be passed before another phase. 


\section{REFERENCE}

Arikunto, S. (2006). Prosedur Penelitian, Suatu Pendekatan Praktik. Jakarta: Rineka Cipta.

Asmani, J. M. (2010). Buku pintar playgroup. Jogjakarta: Bukubiru.

Berk, L. S., Bellinger, D. L., Koenig, H. G., Daher, N., Pearce, M. J., Robins, C. J., ... King, M. B. (2015). Effects of religious vs. conventional cognitive-behavioral therapy on inflammatory markers and stress hormones in major depression and chronic medical illness: A randomized clinical trial. Open Journal of Psychiatry, 5(03), 238.

Brammer, L. M., \& Abrego, P. J. (1981). Intervention strategies for coping with transitions. The Counseling Psychologist, 9(2), 19-36.

Carkhuff, R. R. (2008). The Art of Helping (9th ed.). Amherst: Possibilities Publishing.

Chaplin, J. P. (2001). Kamus lengkap psikologi, cetakan ke-7. Jakarta: PT Raja Grafindo Perkasa.

Corey, G. (2012). Theory \& Practice of Group Counseling (8th ed.). Canada: Nelson Education.

Corrigan, J. D., Selassie, A. W., \& Orman, J. A. L. (2010). The epidemiology of traumatic brain injury. The Journal of Head Trauma Rehabilitation, 25(2), 72-80.

Erikson, E. H. (1963). Childhood and society (Rev. ed.). new york: norton.

Geldard, K., \& Geldard, D. (2011). Konseling Remaja: Pendekatan Proaktif untuk Anak Muda (3rd ed.). Yogyakarta: Pustaka Pelajar.

Gibson, \& Mitchell. (2011). Bimbingan dan Konseling. Yogyakarta: Pustaka Pelajar.

Gladding, S. T. (2012). Konseling Profesi yang Menyeluruh. Jakarta: Indeks.

Goleman, D. (2000). Kecerdasan Emosional: Mengapa EI lebih penting daripada IQ. Terjemahan: Hermaya, T. Jakarta: Gramedia Pustaka Utama.

Gunawan, E. (2014). 26-12-2004: Saat Gelombang Tsunami Menggulung Aceh. Retrieved from http://news.liputan6.com

Homeyer, L. E., \& Morrison, M. (2008). Play as Therapy. American Journal of Play, 1(2), 210-228.

Johnson, R. (2013). Spirituality in Counseling and Psychotherapy: an Integrative Approach that Empowers Clients. Hoboken, New Jersey: John Wiley \& Sons, Inc.

Koenig, H. G., Pearce, M. J., Nelson, B., Shaw, S. F., Robins, C. J., Daher, N. S., ... Pargament, K. I. (2015). Religious vs. conventional cognitive behavioral therapy for major depression in persons with chronic medical illness: A pilot randomized trial. The Journal of Nervous and Mental Disease, 203(4), 243-251.

Lines, D. (2006). Spirituality in counselling and psychotherapy. Sage.

Maba, A. P. (2017). Paradoxical intervention dalam bimbingan dan konseling untuk mengatasi kecemasan. Counsellia: Jurnal Bimbingan Dan Konseling, 7(2), 99-109.

Mulyadi, D. B. I. (2016). Pengembangan Model Konseling Kelompok dengan Teknik Spirituality-Cognitive Restructuring untuk Meningkatkan Self-Esteem Siswa SMA di Kota Semarang. PPs Universitas Negeri Semarang. 
Mulyadi, D. B. I. (2017). Implementasi Konseling Kelompok dengan Teknik SpiritualityCognitive Restructuring untuk Meningkatkan Self-Esteem Siswa. Psikopedagogia, 6(1), $1-10$.

Mulyadi, D. B. I., Christiana, E., Muhari, H., \& Wiryo Nuryono, S. P. (2013). Pengembangan paket bimbingan percaya diri dalam meningkatkan interaksi sosial anak tk aisyiyah kelompok b kota mojokerto. Jurnal BK UNESA, 3(1).

Nawangsih, E. (2016). Play Therapy Untuk anak-anak Korban Bencana Alam Yang Mengalami Trauma (Post Traumatic Stress Disorder/PTSD). PSYMPATHIC, 1(2), 164178.

Pearce, M. J., Koenig, H. G., Robins, C. J., Nelson, B., Shaw, S. F., Cohen, H. J., \& King, M. B. (2015). Religiously integrated cognitive behavioral therapy: A new method of treatment for major depression in patients with chronic medical illness. Psychotherapy, $52(1), 56$.

Perempuan, K. P. (2013). Panduan Penanganan Anak Berkebutuhan Khusus Bagi Pendamping (Orang Tua, Keluarga, dan Masyarakat). Jakarta: Kementrian Pemberdayaan Perempuan dan Perlindungan Anak Republik Indonesia.

Plumb, A. M. (2011). Spirituality and Counselling: Are Counsellors Prepared to Integrate Religion and Spirituality into Therapeutic Work with Clients?/La spiritualité et le counseling: Les conseillers sont-ils préparés à intégrer religion et spiritualité dans le travail thérapeutique avec clients? Canadian Journal of Counselling and Psychotherapy (Online), 45(1), 1.

Rahayu, D. (2016). PPosttraumatic Growth Korban Kekerasan pada Anak dan Remaja (Studi di Kota Samarinda).

Riyanto, T., \& Handoko, M. (2005). Pendidikan Pada Usia Dini. Jakarta: Grasindo.

Rohmadheny, P. S., \& Yudiari, N. (2015). Peduli Lingkungan Melalui Kontinuitas Pembiasaan Perilaku Buang Sampah Pada Tempatnya. In Prosiding Seminar Nasional "Optimalisasi Active Learning dan Character Building dalam Meningkatkan Daya Saing Bangsa di Era Masyarakat Ekonomi Asean (MEA)” (pp. 45-49). Prodi Pendidikan Guru Sekolah Dasar dan Prodi Bimbingan dan Konseling.

Saputra, W. N. E., \& Setianingrum, I. (2016). Perkembangan motorik halus anak usia 3-4 tahun di kelompokbermain cendekia kids school madiun dan implikasinya pada layanan konseling. Jurnal CARE (Children Advisory Research and Education), 3(2), 1-11.

Strauser, D. R., Lustig, D. C., Cogdal, P. A., \& Uruk, A. Ç. (2006). Trauma symptoms: Relationship with career thoughts, vocational identity, and developmental work personality. The Career Development Quarterly, 54(4), 346-360.

Sugiyono. (2011). Statistik untuk Penelitian. Bandung: Alfabeta.

Thoresen, C. E., \& Harris, A. H. (2002). Spirituality and health: What's the evidence and what's needed? (Vol. 24). Annals of Behavioral Medicine.

Wibowo, M. E. (2005). Konseling Kelompok Perkembangan. Semarang: UPT Unnes Press. 
Copyright Holder :

(c) Indri M, D. B. (2018)

First Publication Right :

(C) Islamic Guidance and Counseling Journal

This article is under :

(c) (i) (2) 
